\title{
Rural Women Farmers and Sustainable Livelihoods in Guyana
}

\author{
Paulette Henry \\ Faculty of Social Sciences, University of Guyana Turkeyen Campus \\ Turkeyen, P.O. Box 101110, Georgetown, Guyana, South America
}

\begin{abstract}
Rural women in agriculture are legitimized women as productive stakeholders through a process that documents the various roles have played in rural agriculture, the rural economy, and food security. Accounting for $43 \%$ of the world's agricultural labor force, women are important actors in the achievement of Sustainable Development Goal 2 particularly in reducing poverty especially among women, and improving food security. This quantitative study has shown that women have combined their roles in varying fields of agriculture using their income to take care of families while contributing to the economy and food security. Their contributions however are underrecognized due to the gender disparities in the investments made to their male peers in the same business. This may be due to the feminization of rural agriculture coupled with many women not having the literacies required to negotiate the demands of land or loan acquisition and the technical skills to move beyond subsistence agriculture. Notwithstanding, rural women farmers earn income that helps to guarantee the basic livelihoods of their families and contribute to community food security. However, rural women farmers also have limited financial and technical capabilities to conserve their surpluses and increase their economic well-being. Investments by national governments must be made to rural agriculture with specific recognition towards the advancement of women farmers.
\end{abstract}

Keywords: rural women farmers, agriculture, economic wellbeing, food security

\subsection{Introduction}

\subsection{Introduction to the Problem}

Globally and locally rural women farmers have been contributing to the development of agriculture. Women have always been active in producing food crops, processing food, and marketing (Actionaid, 2011) Despite their overall efforts towards improving the overall well-being of their households and communities through food and nutrition security, income generation, and improving rural livelihoods, rural women face various constraints which hamper their efforts to improve their lives and those around them (FA0,2015). Nonetheless, women according to Mucavele (2015) continue to be the backbone of the development of rural and national economies and comprise $43 \%$ of the world's agricultural labor force, which rises to $70 \%$ in some countries. Data on Africa and Asia shows that $80 \%$ of the agricultural production comes from small farmers, who are mostly rural women (Sutton, 2020). Additionally, Mucavele (2015) also stated that whilst women comprise the largest percentage of the workforce in the agricultural sector, they do not have access and control over all land and productive resources. This is a significant factor that underpins a commentary from Michelle Bachelet - Under-Secretary-General and Executive Director of UN Women who in a press release by UN Women (2012) made the connection between women economic empowerment and the range of possibilities that ensue. Bachelet asserts that when women are empowered and can claim their rights and access to land, there are many benefits to be derived since leadership is developed, opportunities and choices 
are created, economies grow, food security is enhanced and prospects are improved for current and future generations.

Guyana ranks 122 out of 189 countries on the United Nations Development Program's Human Development Index and is classified as a middle-income country by the World Bank (UNDP, 2020). Furthermore, the Guyana UNDP human development report records lower workforce participation for women when contrasted with men in the labor market (43.9 percent compared to 68.5 for men). Moreover, even though Guyana is deemed a middle-income country, "3.4 percent of the population (26 000 people) are multidimensionally poor while an additional 5.8 percent are classified as vulnerable to multidimensional poverty (46 000 people). The breadth of deprivation (intensity) in Guyana, which is the average deprivation score experienced by people in multidimensional poverty, is 41.8 percent. The MPI, which is the share of the population that is multidimensionally poor, adjusted by the intensity of the deprivations, is 0.014." (UNDP, 2020, p. 6). Notwithstanding its being among the poorer countries within Latin America and the Caribbean, Guyana is renowned for its natural resources which include fertile agricultural land, minerals, and large swaths of tropical forest.

Most of Guyana's poor and rural population engage in rural small-scale subsistence farming. However, rural farmers have limited technical capacity, institutional support, and the infrastructure to successfully bring their products to market. Resultantly, they often lack the human and financial resources to convert farming activities into strong and sustainable businesses. The challenges to rural small-scale farmers must be recognized within the context of the challenges to traditional agricultural products such as sugar and rice which face severe competition on international markets. But a wide variety of non-traditional products grown by small-scale farmers - including fruits, root crops, vegetables, and spices - have external market potential. These products could represent a major opportunity for economic diversification and growth (IFAD. 2017).

Rural women farmers have grown since men have been moving away in search of more lucrative economic opportunities. The purpose of this quantitative study is to add to the body of knowledge on rural women farmers and their contribution to their economic advancement and food security. It outlines the factors which propelled women's involvement in farming, the type of farming activities in which they became involved, how farming sustained their livelihoods, challenges faced in terms of financing as well as farming education needs. Critically, it points to those factors that can help or hinder the sustainability of rural women farmers. Following an analysis of the experiences and knowledge, garnered from rural women farmers as presented in the findings, recommendations that have evolved out of the unique needs of women farmers in a country that depends heavily upon agriculture are shared.

\subsection{Importance of the Problem}

Women are important actors in the achievement of UN Sustainable Development Goal 2: End hunger, achieve food security and improved nutrition and promote sustainable agriculture. However, reports on the SDGs indicate that there has been a steady increase in persons suffering from hunger since 2015 . Thus "the world is not on track to achieving Zero hunger by 2030. If these trends continue, the number of people affected by hunger would surpass 840 million by 2030" (UNDP, n.d; Regan, 2020). This has serious implications for global and local poverty particularly for women who comprise the large majority of the world's poor with poverty eradication being especially difficult for rural women (UN Women, 2013). Moreover, research shows that women, on average, spend 90 percent of their income on their family, while men tend to spend between 30 and 40 percent, even where the income is insufficient to meet the family's needs (Clinton Global Initiative, 2009; Marslen, 2015). 
Women are seen as 'gatekeepers who dedicate their own time, income, and decision-making to maintain food and nutritional security of their households and communities; and "managers" of the stability of food supplies in times of economic hardship (UN Women, 2013). However the "agricultural sector in many developing countries is underperforming, in part because women, who represent a crucial resource in agriculture and the rural economy through their roles as farmers, laborers, and entrepreneurs, almost everywhere face more severe constraints than men in access to productive resources" (SOFA Team \& Doss, 2011, p. 2). Further, the FAO has acknowledged that "the major constraint to the effective recognition of women's actual roles and responsibilities in agriculture is the scarcity of gender desegregated data to understand role differences in food and cash crop production. The lack of data makes it difficult to determine women's contribution to the production, storage, and marketing of agricultural products. Women need to be involved in sustainable agriculture. Sustainable agriculture, encompasses social, environmental, and economic goals and practices, in opposition to industrial agriculture models of agriculture, which emphasize monocultures, global markets, mechanization, and capital intensiveness (Beus \& Dunlap, 1999; Hassanein, 1999; Schmitz, 2001).

Even though women are recorded as producing between 60 and 80 percent of the food in most developing countries and more than 50 percent of the world's food production, their critical contribution to food security is only now recognized (FAO, 2017). This research on Guyana is therefore important to understand the important role women play in food security. Hence, this research aims to: (i) ascertain those factors which propelled women's involvement in farming; (ii) find out the type of farming activities in which they became involved (iii) examine how has farming sustained their livelihood (iv) outline women's experiences with technical and human resources to sustainable farming. Ultimately, the questions which this research answers are(i) How has farming contributed to the economic wellbeing and food security of rural women in Guyana? (ii) What have been the experiences of rural women farmers in seeking to sustain their livelihoods and economic well-being?

\subsection{What the Literature Says?}

The multiplicity of tasks in which rural women farmers engage points to the complexities of their pursuit of agriculture as an economic form of support. It is for this reason that both the SOFA Team and Doss (2011) suggest that rural women farmers manage complex households. The writers pointed to women pursuing multiple livelihood strategies, which includes child-rearing and caring for their families with activities also including the production crops, tending animals, food processing, and finding sale for produce with some working for wages either in agricultural or other fields. These complexities vary by community and context. Nonetheless, there is an inherent commonality: multiple activities, family care, and low income. Many of these activities are not defined as "economically active employment" in national accounts but they are essential to the wellbeing of rural households (SOFA Team \& Doss, 2011). Whilst rural women turn to agriculture for their livelihood, the agricultural sector in many developing countries is failing. Writers have suggested that this could be linked to the fact that women are affected by more severe constraints than men in accessing productive resources (SOFA Team \& Doss, 2011; Actionaid, 2013). To survive under these generally unfavorable conditions, rural women farmers tend to diversify their income sources between farm and non-farm activities, and between family-owned enterprises and wage labor. Additionally, "most of the work on farms is done by women, who support themselves and their children” Buvinic \& Mehra, 1990, p.1).

\subsubsection{National Governments' Response to Women in Agriculture}

Efforts by national governments and the international community to achieve their goals for agricultural development, economic growth, and food security will be strengthened and accelerated if they build on the contributions that women make and take steps to alleviate these constraints. However, it is believed that 
women are not recognized as farmers by their own families or communities, and not by governments or donors (Bedi, 2018). This approach to women in agriculture seems to be rooted in patriarchal stereotypes about men and women's rights and roles, traditional values, and cultures, as well as the current global economic model all come together to generate and reinforce why women are not recognized as equals in society, more so as farmers. Despite incremental changes, women have traditionally been denied much of the agricultural ownership and leadership opportunities awarded to their male counterparts (Tosh, 2021). This is compounded by actual policies, legislation, and practices within varying contexts where women are located. In Uganda researchers also highlighted that gender norms hold back agriculture due to social values and perceptions of 'women's role' as much as by structural disadvantage as these restrict women's access to farming assets and agribusiness value-chains (ODI, 2021). Thus the needs of women farmers are ignored when it comes to policy, legislation, extension services, research, or other government support. The Jamaican scenario of rural women in agriculture includes the absence of adequate social safety nets for rural small scale farmers especially women when affected by climate change and natural disasters (FAO, 2013). In many countries government's response usually focuses on large landowners within the economy. Furthermore, there is the need for "research on sustainable and labor-intensive agricultural production systems and rural off-farm production and enterprise development" (Polman, n.d, p.13). Further, the author proposed that government policies "should promote agro-industries based on local resources with institutional linkages between them and small farmers and rural workers, through their own self-reliant, representative and self-managed organizations, including the agricultural cooperatives" (p. 13).

Under Guyana's constitution, all persons have equal rights and opportunities. Guyana is also a signatory to CEDAW, the Beijing Platform Action, and several other international covenants which underscores the rights of women and espouses gender equality. The inalienable rights of women are reiterated within the Guyana National Development Strategy, (NDS, 2017) which states that legally women are neither denied access to loans, mortgages and credit nor required to have consent from their husbands or male partners to obtain credit. However, the literature points to gender-specific obstacles which place women farmers at a disadvantage. These according to Duckett (2015) include lack of access to land, financing, markets, agricultural training and education, suitable working conditions, and equal treatment. Supporting rural women is a way of breaking the vicious cycle that leads to rural poverty. Hence development strategies should pay special attention to the skills needed for the economic development of women. There is also a need for the right infrastructure to reduce transaction costs, scale up to commercial agriculture and improve the processing of agriculture products, and reduce post-harvest losses (World Bank, 2021).

In some countries, there have been efforts at gender lens investing. This is seen to have positive impacts on the livelihoods of women and their families (Sweeney \& Levine, 2020). The feminization of agriculture has been referred to as the feminization of agrarian distress since the increased representation of women in agriculture has not significantly contributed to women's socio-economic empowerment since their decisionmaking power remains limited (Asadullah, 2020). ). Investment in rural agriculture requires the right policies along with access to technology. And as is seen in Asia similar to other countries with rural agriculture, the business of agriculture could be unpredictable (Asadullah, 2020). Concomitantly, three recommendations have been put forward to governments. These ask governments to (1) develop a newly conceived policy agenda for agricultural extension and communication for rural development; (2) to adopt a diversified and pluralistic national strategy to promote agricultural extension and communication for rural development; and (3) to build a platform for dialogue and collaboration with the relevant institutions that comprise the diversity of multi-sectoral agricultural extension service providers that exist in most countries. The purpose of these recommendations is to advance the livelihoods, i.e., food security and income generation, of poor people in rural areas" (FAO, 2003, p. 1). The benefits to women redound to families and 
communities.

\subsubsection{Rural Women Farmers, Poverty, Land, and Financial Security}

Poverty according to (Polman, n.d.) correlates with hunger and food insecurity. Therefore, governments must be intentional in supporting rural women's agricultural pursuits due to its projected long-term beneficial impact. Mucavele (2015) established that policies for the benefit of rural women should be tested and reassessed by the women, using them as a social learning tool and not as individuals on whom political authority is exercised. Rural women must be treated as partners and experts who have invested in agriculture and possess knowledge that complements experts' formal knowledge. CARICOM (2011) endorsed reports that within the Caribbean, rural women require a special financial arrangement tailored to meet their needs. This it was suggested could be introduced to the agricultural banking system of member states, or a cooperative/credit union can be established for rural women. The premise underscoring this suggestion was that structured financing to support women would facilitate a disaster management scheme, Agricultural insurance for women farmers especially small business and fisher folks against natural disasters (hurricanes, drought, floods, and earthquakes, etc.) which affect the region; assist with loans, especially for micro, small and export challenges; and would also be charged with the responsibility of giving oversight on the group/cottage industries or community-based agricultural activities with the potential to grow.

The ownership of land is very important to rural women. Women farmers who own land "tend to be economically independent and mobile" (Buvinic \& Mehra, 1990, p.1), giving them an advantage in the agrobusiness. This is because land translates to money and provides access to loans. However, land use must also be central to the discourse for women farmers. Research suggests that women express more concern for the environment, support policies that are more beneficial to the environment, and tend to vote for leaders who care about the environment (United Nations, 2009, Millennium Development Goals Report).

The literature has legitimized the idea of women as productive partners in agriculture, discovering and documenting the various roles played by women as farmers, farm wives, and agricultural professionals while recounting the stories of successful women in these roles (Begum \& Yasmeen, 2011; SOFA Team \& Doss, 2011; Davidson, 2017). Research from the 1980s and 1990s has provided deeper insights into women's roles and contributions to agriculture exist (Gold \& Effland, 1998; Sofa \& Doss, 2011). Whether women farm, on their own, on family farms, tend gardens, livestock, or assist in the fields, they have been contributing to the advancement of rural economies (Begum \& Yasmeen, 2011).

In many cultures are families and communities are dependent on women farmers for food production (Mengesha, 1990; Gold \& Effland, 1998). Hence advancing the importance of rural and farm women as key stakeholders is critical to successful approaches to food security. Resultantly, over the last two decades, some attention has been placed on empowering women in the varying agriculture sectors either as farmers, or professionals. For women in developed countries, the focus has largely been on identifying and removing barriers to full participation in the work and rewards of agriculture and rural development. UN Women anticipates that if more women in agriculture had similar access to resources as men agricultural output would increase exponentially thereby reducing the percentage of hungry people particularly in countries with the greatest need (UN Women, 2013). More recently, studies of women have also begun to analyze the effects of programs and policies on rural women directly. However, Mengesha (1990) asserts that research on women in agriculture fails to adequately address several key issues on the critical roles of women in agriculture. Women's participation in agriculture and the rural economy is therefore key to reducing poverty rates since food insecurity issues continue to worsen (FAO, 2018). Gender equity must therefore become a major development objective as awareness of the contribution which rural farming women can make. In this era of climate change, women who have limited access to resources, and carry the double burden of paid 
work and unpaid childcare/home labor must be empowered with resilience to climate change and food security (Sutton, 2021).

In Guyana, several key laws have been passed to empower women and promote gender equality, however, the country still lags behind the rest of the developed and developing world. Laws and policies without the appropriate institutional support systems to monitor its implementation cannot catalyze the progress of rural women farms nor improve their overall contributions and output towards poverty reduction and the country's economy. Consequently, the lack of influence that women have in this sector denies Guyana's agriculture sector half the potential of its workforce. Guyana has had a rich history of women in agriculture (Odie-Ali, 1986; Cumberbatch, 2011). However, how agriculture is portrayed needs to change to encourage women into the agricultural sector thereby reducing isolation and migration from rural farming communities. Women must be encouraged to lead within a sector that is critical to their livelihoods and food security. take an active part in the creation of a successful agricultural future.

\subsection{Method}

The quantitative study conducted in four rural agricultural farming communities in Guyana was guided by the assumption that rural farming women can contribute to their economic livelihoods and food security. In seeking answers to the two research questions on how farming has contributed to the economic wellbeing and food security of rural women in Guyana as well as what have been the experiences of rural women farmers in seeking to sustain their livelihoods and economic well-being, a survey was conducted to gather data. The pre-tested survey instrument was given out by field extension workers with whom the women interacted. The Statistical Package for Social Scientists (SPSS) was used for data analysis, and thematic trends were analyzed in both the documents studied as well as the survey findings.

\subsection{Sampling Procedures}

The sample population was drawn from women farmers in a predominantly agricultural region along the coast in Guyana. Women farmers are fewer in number than male farmers. Thus this sample was purposively selected from among the list of women farmers who accessed the services of the agricultural extension officers in this region. These women were drawn from among women who are engaged in some form of agricultural activity. These include cash crops, poultry farming, cattle rearing, or other related farming activities. Hence thirty women were drawn from four communities known for extensive farming. The purpose of the study was explained to participants who were assured of their anonymity as well as their right to withdraw at any time. No defining features were used on the instruments in collecting the data.

\subsubsection{Sample Size}

The sample included thirty women farmers who had accessed the services of the regional agricultural extension officers within the year and were actively engaged in farming.

\subsection{Results}

\subsection{Demographic Data}

This section provides demographic data on Guyana's rural women farmers. As shown in Figure 1, rural women farmers largely represent the ethnic diversity of Guyana. 


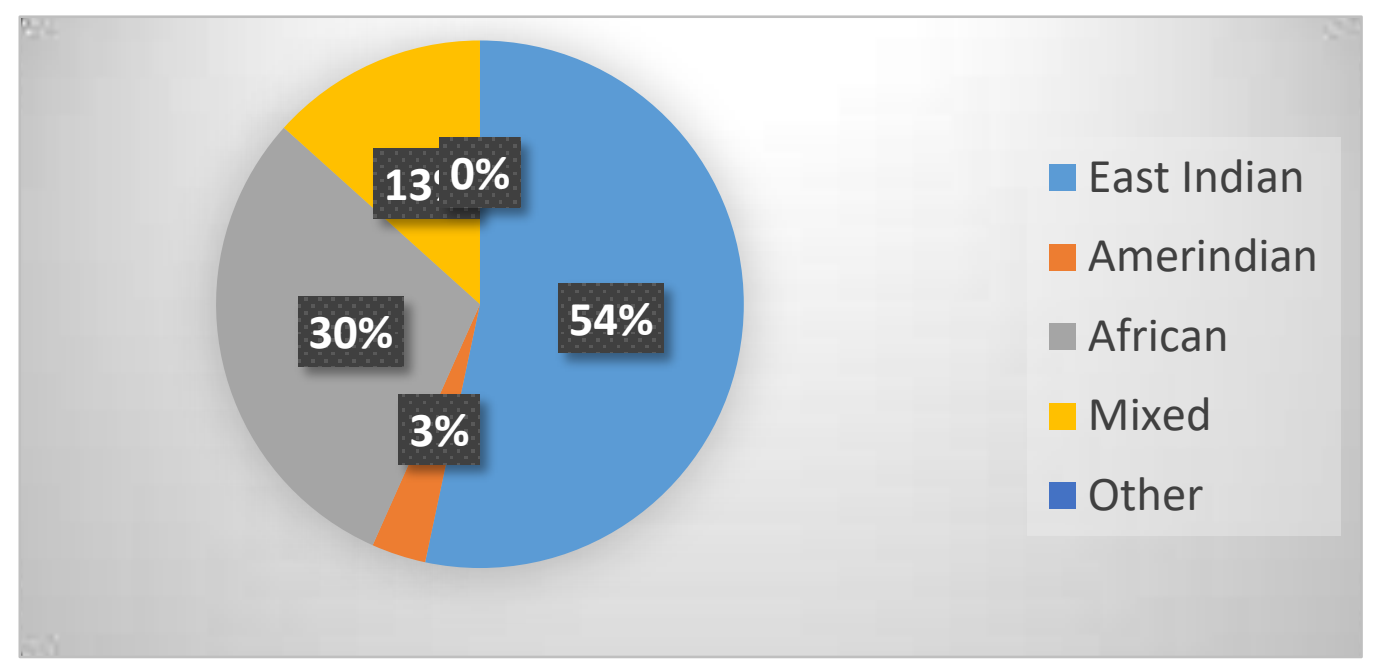

Figure 1. The ethnic composition of rural women farmers Region 6, Guyana

The majority of the participants were between ages 36 to 45 (53.3\%), followed by those who were aged 26 to $35(26.7 \%)$ with the others $(20 \%)$ being under 25 or over 45 . Of significance though, the data showed that $90 \%$ of women engaged in rural farming are between ages 15 to 45 years. This points to a relatively young population who would not only be within childbearing age but also are more likely to have a family. As shown in Figure 1, the majority (54\%) of rural farmers are East Indians followed by persons of African descent (30\%), with the others making up $16 \%$. It must however be stated that this research was conducted in Region 6, East Berbice, Guyana, a region where East Indians are the dominant ethnic group.

\subsubsection{Family Status.}

A look at the marital and family status of rural farmers provided several useful insights. When examined by marital status, there is a similarity in the number of persons who were either single, divorced (50\%), and those who were married or in common-law relationships comprised the other $50 \%$. Thus many of the women in the study were either farm wives or from a farm family. The large majority of the women had at least one child, (93.3\%) with $60 \%$ of the women having four or more children. Only $6.7 \%$ of the women were recorded as having no children. Figure 2 shows that engagement in farming activities takes away from the family time of women who seek to eke out their livelihoods from farms. The three issues cited by women were time to finish chores at home $(50 \%)$, less family time $(43 \%)$, and limited time for self-care (7\%). These all point to the personal sacrifices farming families endure.

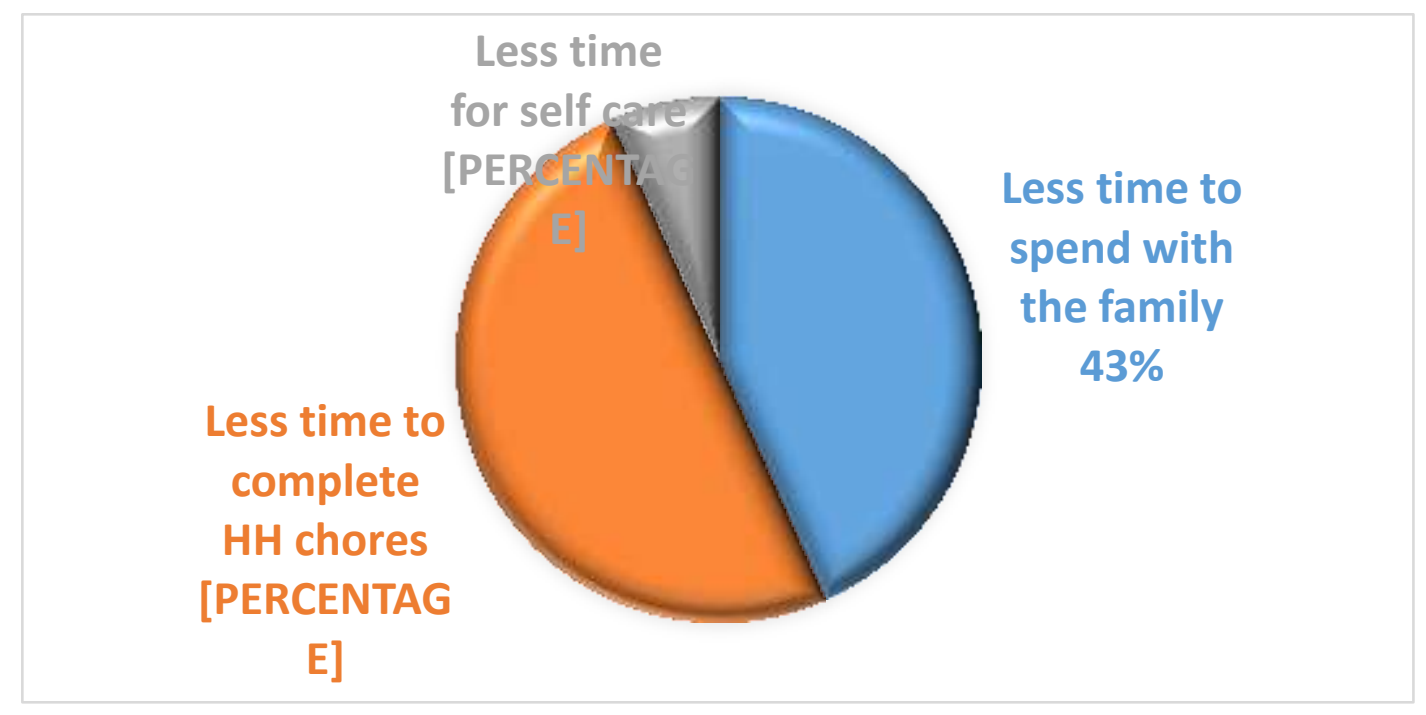

Figure 2. Family time and farming activities 


\subsubsection{The Academic Profile of Women.}

An analysis of the academic status of the women farmers points to varying levels of academic attainment. As shown in Figure 2, at least one-third of the women did not complete primary school whilst an additional one-third did not complete secondary school, with only $6.7 \%$, attained University level education.

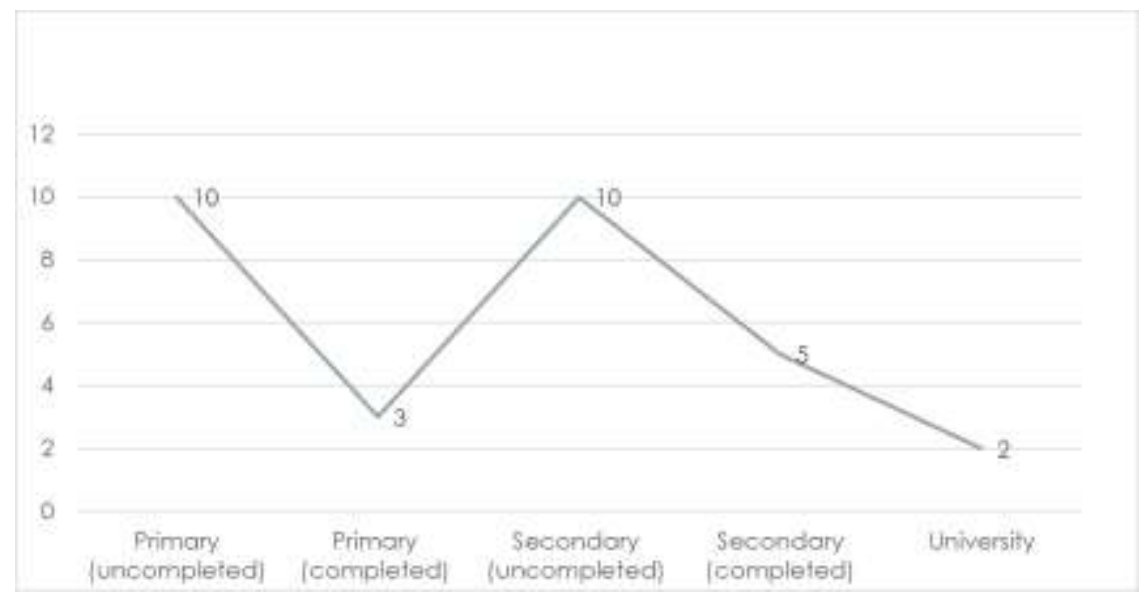

Figure 3. Education level of rural women farmers

Despite the important roles women play in agricultural economies, empirical data revealed a higher level of incompletion of school among women. One-third of the women (10 or 33\%) did not complete primary school, with only 5 or $17 \%$ complete secondary school. Thus more than three-quarters of the women surveyed did not complete secondary education (76.7\%). The story of Guyana's rural women is similar to those in other countries with similar contexts. Very often, rural women with limited education are most likely to be the visible face of poverty (FAO, IFAD, ILO, 2010). Low literacy is believed to be a consequence of education level coupled with the possibility of the non-involvement of rural women in the training as well as the design and planning of programs and policies, that reflect the real and specific needs of rural farming women. These suggest that rural women's deficits in education have broader and longerterm implications for family well-being and poverty reduction.

\subsubsection{Length of Time in Farming.}

The study also sought to find out from the respondents the length of time they have been engaged in farming. The data showed that $73.3 \%$ were in farming for more than 6 years whilst $26.7 \%$ of the women have been farming for more than 10 years (See figure 3).

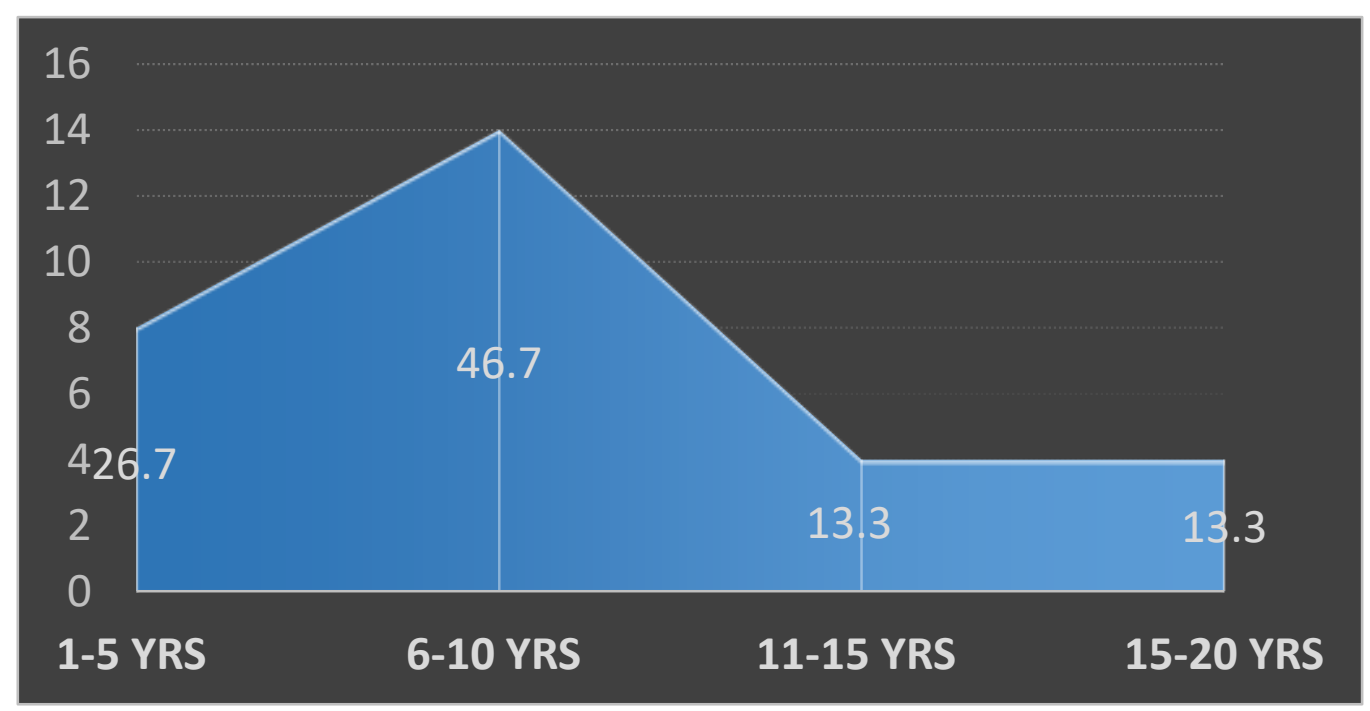

Figure 4. No of years women engaged in farming 


\subsubsection{The Main Source of Livelihood.}

The data show that $53.3 \%$ of rural women farmers rely on farming as their main source of livelihood with the remaining women $(46.7 \%)$ stating that farming was not their main source of livelihood but was used to supplement their income from their primary job. This is corroborated in Figure 4 where $60 \%$ of those surveyed indicated that the reasons for farming were to sustain their livelihoods, with $30 \%$ using farming to supplement their other income while $6.7 \%$ were concerned with having healthy eating options with a small percentage wanting to gain farming experience $(3.3 \%)$. This data reinforces the views posited by other writers who have articulated the complexities of farming and livelihoods for rural women noting that very often farming is used to supplement their income as they seek multiple livelihood strategies (SOFA Team \& Doss, 2011). It may also be noted that women farmers may not have the farming literacies to sustain their livelihoods through farming since more than 90 percent of those participating in the study either did not complete primary or secondary education.

Table 1. Reasons for women entry into farming/agriculture

\begin{tabular}{|l|l|l|}
\hline Reasons for farming & No. of women & Percentage \\
\hline $\begin{array}{l}\text { Maintain family/only source of } \\
\text { livelihood }\end{array}$ & 18 & 60 \\
\hline Boost income/Earn extra income & 9 & 30 \\
\hline Healthy living & 2 & 6.7 \\
\hline Gain experience & 1 & 3.3 \\
\hline
\end{tabular}

\subsubsection{Type of Farming}

One of the key objectives of this study was to ascertain the types of farming in which Guyanese women farmers were engaged. It was found that the women's farming options were diverse as they were engaged in both livestock and crop farming with an even split between the two (50-50\% respectively). Table 5 outlines the types of farming. When examined by category, the data show that for those who reared livestock, poultry farming was higher among women (63.4\%), followed by small ruminants $36.6 \%$ (sheep and goats) as preferred choices. In terms of crops, a variety of options were given with many of the women indicating that they farmed more than one type of the crops. Notably only $2(6.7 \%)$ of the women were engaged in rice production. Rice production is one of the larger production crops which require significant overhead investment.

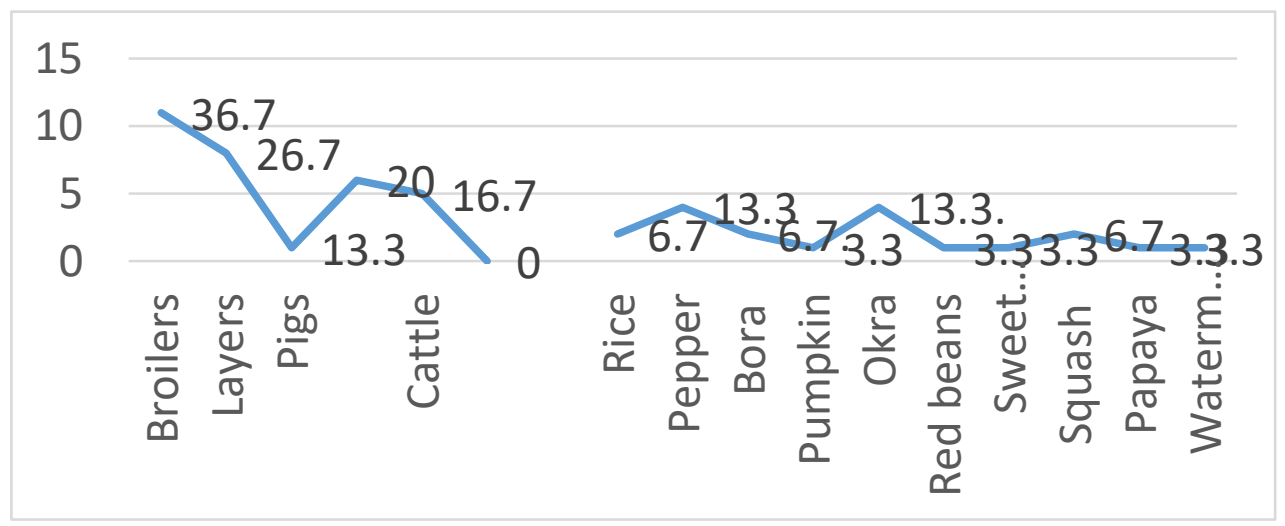

Figure 5. Types of farming 
Table 2. Reasons why rural women farm

\begin{tabular}{lll}
\hline Reasons for farming & No. & Percentage \\
\hline $\begin{array}{l}\text { Maintain family/ Only } \\
\text { source of income }\end{array}$ & 18 & 60 \\
$\begin{array}{l}\text { To Boost income /Earn } \\
\text { an extra income }\end{array}$ & 9 & 30 \\
$\begin{array}{l}\text { For a Healthy living/life } \\
\text { style }\end{array}$ & 2 & 6.7 \\
\begin{tabular}{l} 
To Gain experience \\
\hline
\end{tabular} & 1 & 3.3 \\
\hline
\end{tabular}

Table 2 shows the reasons why Guyana's rural women enter into farming. The primary reason for Guyana's rural women going into Agriculture is for income generation primarily to maintain their families. This is similar to most countries with rural women farmers (Sutton, 2020; Asadullah, 2020). As the data shows, $90 \%$ of rural farming is a source of income for $90 \%$ of the women with only $60 \%$ of these women being solely dependent on their farming income.

Table 3. Reasons for choice of farming/agricultural activity

\begin{tabular}{|l|l|l|}
\hline Reasons for choice of type of farming/agro activity & $\begin{array}{l}\text { No. of } \\
\text { women }\end{array}$ & Percentage \\
\hline Crops are payable all the time & 19 & 63.3 \\
\hline Additional income & 8 & 26.7 \\
\hline Crops can be cultivated in large amounts & 6 & 20 \\
\hline Easy maintenance & 4 & 13.3 \\
\hline Harvest large amount & 3 & 10 \\
\hline Easier to harvest & 2 & 6.7 \\
\hline Maintain livelihood & 2 & 6.7 \\
\hline Crops are used by everyone & 1 & 3.3 \\
\hline Easy to market & 1 & 3.3 \\
\hline
\end{tabular}

Women also justified their type of agricultural activity as shown in Table 3. In sum, the primary reasons provided included the financial returns on their investments $(90 \%)$ and the low maintenance costs. It is important to note too that women consider crops that are used frequently, easy to harvest (6.7\%), and easy to market $(3.3 \%$.) These are important considerations for women who may not have access to farm help, technology, and other resources to lighten the burden upon their agro-business.

Additionally, when asked about the income generated from farming, Figure 5 shows that only a very small percentage of women earned above GYD 100,000 or USD 500 with more than $50 \%$ of the women earning less than GYD 50,000 or USD 250 from their production activities. This serves to explain rural women's poverty and its implications for their social and economic well-being. 


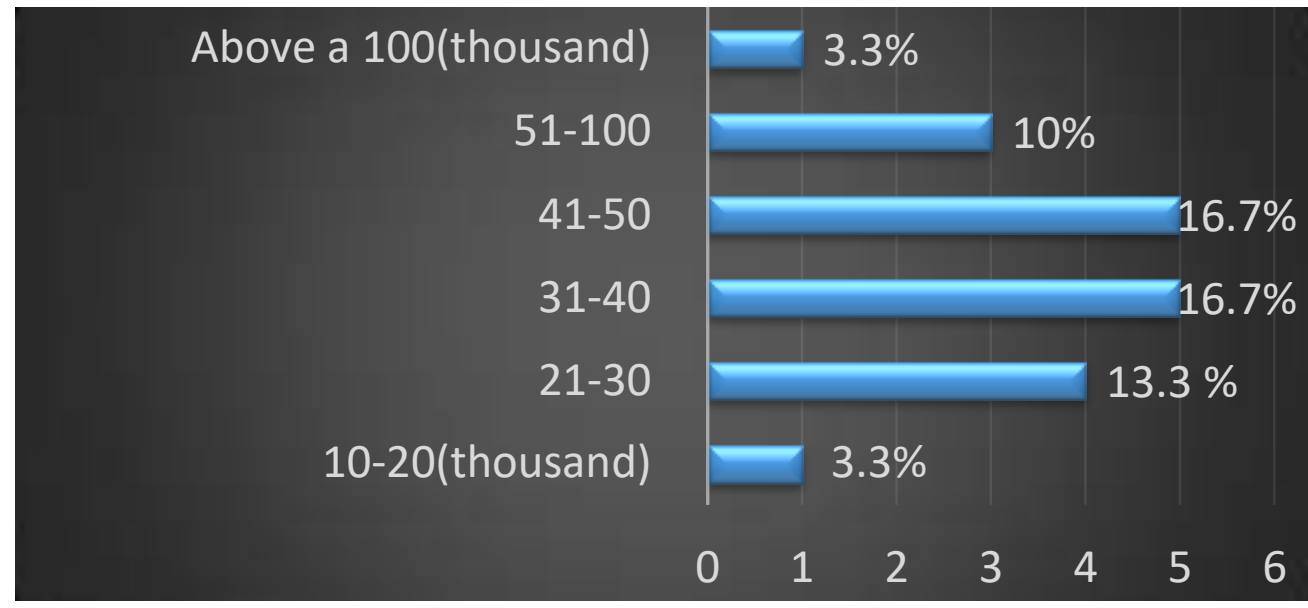

Figure 6. Income about GYD 100000/USD 500

\subsubsection{Land Ownership.}

Table 4. Type of land occupation

\begin{tabular}{|l|l|l|}
\hline Type of Occupation & $\begin{array}{l}\text { No women } \\
\text { surveyed }\end{array}$ & Percentage \\
\hline Titled/transported & 5 & 17 \\
\hline Leased & 8 & 27 \\
\hline Rented & 3 & 10 \\
\hline Family property & 10 & 33 \\
\hline Squatting & 4 & 13 \\
\hline
\end{tabular}

Land is perhaps the most important asset for rural women farmers, which is needed to support the production of food and income security. Table 4 shows that the majority of rural women surveyed do not own the lands on which they farm. Of the 30 women, only 5 or $17 \%$ of women farmers had legal title to their lands, with 8 or $27 \%$ having leased the land, 4 or $\%$ were squatting and 3 or $10 \%$ were renting lands. The rental has a cost and further implications to income, whereas squatting may not be advantageous since these women could be removed from the land for illegitimate occupation based on the owner's right to be in private or government's. Yet data from the present study showed that due to a range of legal and cultural constraints in land inheritance, ownership, and use, less than $25 \%$ of rural women farmers surveyed owned land.

\subsubsection{Support Needs of Women on the Farms}

Table 5. Support to women on the farm

\begin{tabular}{|l|l|l|}
\hline Support on the farm & No & Percentage \\
\hline Worked alone & 6 & 20 \\
\hline Children & 16 & 53.3 \\
\hline Employed persons & 7 & 23.3 \\
\hline Husband/partner & 1 & 3.3 \\
\hline
\end{tabular}

The research sought to ascertain what forms of support or 'assistance were available to women to undertake their farming activities. Table 5 shows that the main support for women was from either their children (16 or 53.3), with 6 or $20 \%$ of the women indicated that they often worked alone. Less than $25 \%$ of the women (7) were able to pay employees. Hence, 17 or $76.6 \%$ of the support on farms was provided by the family. 
Table 6. Challenges identified by women farmers

\begin{tabular}{|l|l|l|}
\hline Challenges identified & No. of women & Percentage \\
\hline Land preparation & 4 & 13.3 \\
\hline Lifting weight & 3 & 10 \\
\hline Doing physical work & 4 & 13.3 \\
\hline Supply of water & 6 & 20 \\
\hline Stigma & 3 & 10 \\
\hline Farming equipment & 5 & 16.7 \\
\hline Spraying of crops & 4 & 13.3 \\
\hline Harvesting & 1 & 3.3 \\
\hline
\end{tabular}

Table 6 outlined the challenges faced by Guyana's women in farming. The challenges reported are related mainly to labor-intensive activities such as land preparation activities, water supply, and harvesting, and other activities which require heavy lifting. These can be reduced. These laborious challenges are not unique to women and can be overcome with the use of modern technologies. Unfortunately, the high cost of this equipment and technological advancement makes them inaccessible to rural women farmers many of whom reported earning less than GYD 50,000 or USD 250 monthly from their farming.

\subsubsection{How Women Sell Their Produce}

As shown in Figure 6 shows, women use a combination of methods in the sale of their produce. Fifty-three percent stated that they sold their produce themselves. Additionally, $27 \%$ of the women stated that they wholesaled their produce whereas $20 \%$ stated that they did a combination of wholesale as well as direct sales.

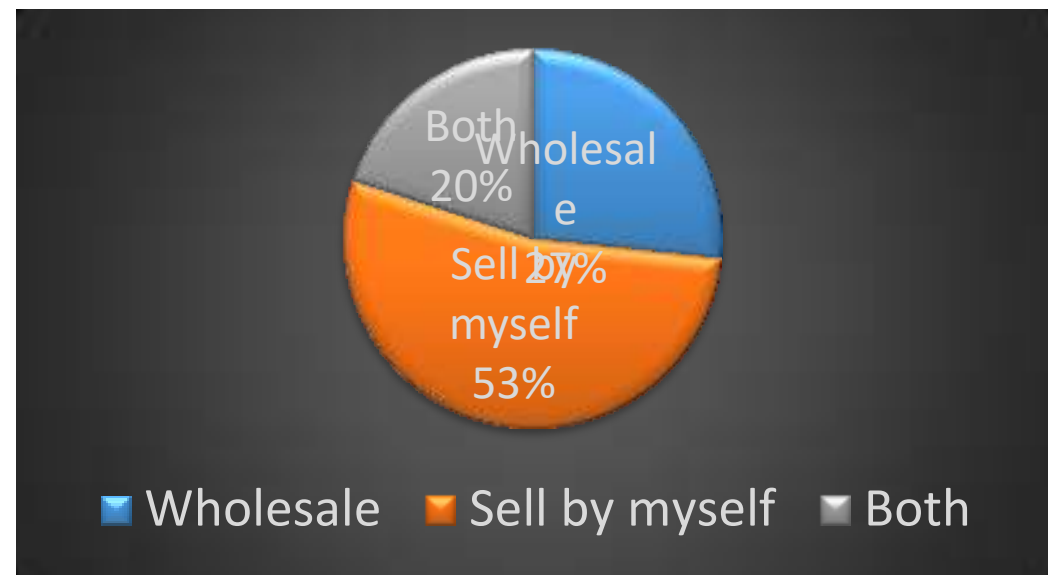

Figure 7. How women marketed their produce

\subsubsection{Support Needs of Rural Women Farmers}

Table 7. Short term support needs of women farmers

\begin{tabular}{|l|l|l|}
\hline Short support needs of women respondents & No of women & Percentage \\
\hline Transportation of produce & 11 & 36.7 \\
\hline Finance & 6 & 20 \\
\hline Access to land & 5 & 16.7 \\
\hline Training & 5 & 16.7 \\
\hline Drainage and irrigation & 3 & 10 \\
\hline
\end{tabular}


Women farmers outlined their short and long-term support needs in order of priority. The top necessities identified by the women in were in order of priority were the transportation of produce (11 or 36.7\%) and finances (6 or $20 \%$ ). Both access to land and training were equally ranked (5 or $16.7 \%$ ). However, draining and irrigation were the least among their immediate support needs (3 or 10\%).

When asked about their longer-term needs, $56.7 \%$ of the women stated that they need finances to expand. Their additional needs also included training to better manage their farms $(26.7 \%)$, rebates from governments concerning the costs on farming equipment $(26.7 \%)$, increased knowledge on new farming techniques $(26.7 \%)$, protection from animals that destroyed their produce (10. \%), and physical assistance on the farm $(6.7 \%)$.

\subsection{Discussion}

This study confirms that farming is important to the livelihoods and food security of rural women in Guyana. Similar to other rural women farmers globally, they play an important role in contributing to their rural economies (FA0,2015; Mucavele, 2015; Sutton, 2020). And while this research cannot be generalized

to the national population as it was only conducted in four communities within one agricultural region in Guyana, it offers some useful insights to provide a deeper understanding of the first-hand experiences faced by rural farming women

While the women have been able to eke out a living from subsistence farming, more is required for sustainable farms. The state of many rural women has been linked to low literacy levels, poor financing, and land ownership. The majority of women in this study (75\%) have not completed secondary education. This could negatively impact the literacies needed required in the technicalities of farming production as well as managing farming businesses. Additionally, most women have recorded limited access to finances, do not own farmlands which can also enable access to finances, and are not e4ngaged in the decisions on agro management. Resultantly, as confirmed by other researchers, most of these farm women are self-financing and highly dependent on family members for the supply of labor (Buvinic \& Mehra, 1990).

For Guyanese rural women to contribute significantly to increases in food production and food security as well as to the rural economy mere financial support is not sufficient. There must be able to participate in the type of agricultural activities that respect the environment and contribute to the conservation of natural resources while ensuring food security and sustainable livelihoods.

Environmental degradation has a great impact on natural resources, which rural women rely on for their livelihoods. Thus, the training of rural women is very important, especially in the areas of adoption of modern agricultural techniques that are tailored to local conditions and where natural resources are used sustainably. This requires agricultural extension workers to understand the needs of women, the ecological techniques and impart them in ways that are both understandable but advantageous to both women and the land from which they garner their livelihoods. While women's involvement has been associated with better local environmental management, their mere presence in institutions is not enough to overcome institutionalized systemic disparities. Holistic changes within nimble systems must ensure that women can participate effectively in decision-making related to rural agriculture.

Rural women in agriculture have placed attention on the gendered and social disparities which exist in the agricultural industry. Similar to the experiences faced by Guyanese women, many other countries fail to recognize the important role of women play in the economy and safeguarding their livelihood (SOFA Team \& Doss, 2011; FAO, 2017). 
For the majority of rural women farming is the main base of their family's income. The women manage their agricultural pursuits as a family business with their children and partner (where present) being their farmhands. However, there is a need for strengthening the network of public services in rural areas including health, education, and welfare services, as well as establishing policies and programs that combat and protect rural women against the effects of climate change. Giving support to rural women is a way of breaking the vicious cycle that leads to rural poverty or family migration from rural communities. It is extremely important to recognize the role that rural women play and the contribution that they make, by giving them greater political and financial support and involving them in programs that enhance women's role in agricultural production.

Guyanese rural women farmers can become leaders within the farming communities and also become role models, with the capacity to empower, inspire and teach other women and men. The national agricultural policy or framework must be reframed to encourage women's active engagement in agricultural policy and practice. Failure to do so not only creates gender inequity but also limits the potential of a large portion of Guyana's rural workforce.

\subsection{Conclusions and Recommendations}

Rural women of Guyana together with their children form a major segment of the agricultural labor force for cash-crop and livestock productions. Apart from farming rural women farmers have added domestic and caregiving responsibilities, resulting in them having to work far more hours than men. As a result of their efforts in agricultural production, rural women farmers can earn income that helps to guarantee their selfsustenance. Women as the lead person on their farms and with family dependents must be able to generate an income that meets more than the day-to-day needs. They must be able to meet other needs, such as health care, paying for the education of their children, or the acquisition of other products and goods which are necessary for a reasonable quality of life. Investments in rural women can assist Guyana in reducing gender poverty while ensuring food security. However, this requires investments that are financially viable and more sustainable.

Investments must be accompanied by more comprehensive measurement systems to assess the different impacts of agriculture and rural development policies and programs for rural women. Additionally, extension systems should be strengthened to be more responsive to and inclusive of women. Strengthening agricultural systems in which women operate benefits not only women and their families, but ripples out to the rural economy and the country.

\section{Acknowledgments}

This research is the work of Dr. Paulette Henry and Dr. Grayson Halley. We wish to acknowledge the support of the field extension workers in helping us to identify the women participants in this study.

\section{References}

1. Actionaid International. (2011). What women farmers need: A blueprint for action. https://actionaid.org/sites/default/files/the_blue_print_for_women_farmers.pdf

2. Arigbede, R., \& Kolade, O. (2004). Constraint to women's participation in agricultural production in rural areas of Kaduna State, Nigeria. Journal of Agricultural Research and Development, 9(2).

3. Asadullah, M. N. (2020). Farming could empower millions of women across South Asia-here's how. World Economic Forum. https://www.weforum.org/agenda/2020/07/farming-female-empowerment$\underline{\text { agriculture-gender }}$ 
4. Bedi, B. (2018). Recognizing women as farmers. India Development Review. https://idronline.org/recognising-women-as-farmers/

5. Begum, R., \& Yasmeen, G. (2011). Contribution of Pakistani women in agriculture: Productivity and constraints. Sarhad Journal of Agriculture, 27(4), 637-643.

https://www.aup.edu.pk/sj_pdf/CONTRIBUTION\%20OF\%20PAKISTANI\%20WOMEN\%20IN\%2 OAGRICULTURE.PDF

6. Bolger, D. (2010). The dynamics of gender in early agricultural societies of the near east. Signs: Journal of Women in Culture and Society, 35(2), 503-531.

7. Buvinic, M., \& Mehra, R. (1990). Women in agriculture: What development can do. https://www.icrw.org/wp-content/uploads/2016/10/Women-in-Agriculture-What-Development-CanDo.pdf

8. Clinton Global Initiative. (2009). Empowering girls \& women. https://www.un.org/en/ecosoc/phlntrpy/notes/clinton.pdf

9. Covarrubias, K., Nsiima, L., \& Zezza, A. (2012). Livestock and livelihoods in rural Tanzania: A descriptive analysis of the 2009 National Panel Survey.

https://openknowledge.worldbank.org/bitstream/handle/10986/17886/866280WP0Lives00Box38518 1B00PUBLIC0.pdf? sequence $=1 \&$ is Allowed $=y$

10. Crawford, M. (2013). Women farmers' limited “access to". Jamaica Network of Rural Women Producers. http://www.wfo-oma.com/women-in-agriculture/articles/women-farmers-limitedaccess-to.html

11. Cumberbatch, K. (2011). A case study on gender inequality in the agricultural sector of the Mahaicony Village, Guyana, and its impact on the economic development the area. https://www.academia.edu/7389384/Agriculture_and_women_in_rural_Guyana

12. Davidson, N. (2017). Women in farming and the agriculture sector: Research report. https://www.gov.scot/publications/women-farming-agriculture-sector/pages/9/

13. Duckett, M. (2015). Empowering female farmers to feed the world. https://www.nationalgeographic.com/culture/article/partner-content-empowering-femalefarmers

14. Effland, A. B. W., Gold, M. V., \& National Agricultural Library (U.S.). (1998). Women in agriculture and rural life: An international bibliography. https://naldc.nal.usda.gov/download/7095646/PDF

15. FAO. (1996). Women: The key to food security. http://www.fao.org/3/x0171e/x0171e02.htm

16. FAO. (2011) Women in agriculture closing the gender gap for development. http://www.fao.org/publications/sofa/2010-11/en/

17. FAO. (2013). Climate change and agriculture in Jamaica agricultural sector support analysis. http://www.fao.org/3/i3417e/i3417e.pdf

18. FAO. (2017). Women and sustainable food security. http://www.fao.org/3/x0171e/x0171e02.htm

19. FAO. (2018). Part 1: Food security and nutrition in Asia and the Pacific: An update. http://www.fao.org/3/CA0950EN/ca0950en.pdf

20. Hill, C. (2011). Enabling rural women's economic empowerment: Institutions, opportunities, and participation. UN Women In cooperation with FAO, IFAD and WFP. https://www.un.org/womenwatch/daw/csw/csw56/egm/Hill-BP-1-EGM-RW-Sep-2011_CH.pdf https://www.renature.co/articles/empowering-women-in-agriculture/ 
21. Jensen, J. M., \& Effland, A. B. W. (2001). Introduction. Frontiers: A Journal of Women Studies, 22(1), iiixvii. http://www.jstor.org/stable/3347064

22. Marslen, T. (2015). Empowering women in agriculture: Australia and beyond. https://www.futuredirections.org.au/publication/empowering-women-in-agriculture-australia-andbeyond/

23. Mengesha, A .(1990). The role of women in agricultural production and household decision making: a cross-cultural comparison between India and Cameroon; Retrieved at: https://core.ac.uk/download/pdf/38900895.pdf

24. Mengesha, A .(1990). The role of women in agricultural production and household decision making: A cross-cultural comparison between India and Cameroon. https://core.ac.uk/download/pdf/38900895.pdf

25. Mucavele, S. (2015). The role of rural women in agriculture: Women, gender and development, Republic of Mozambique - Southern Africa. http://www.wfo-oma.com/women-inagriculture/articles/the-role-of-rural-women-in-agriculture.html

26. National Development Strategy (Guyana). (2017). https://finance.gov.gy/wpcontent/uploads/2017/06/nds.pdf

27. ODI. (2021). New ODI study shows how gender norms are holding back agriculture in Uganda. https://odi.org/en/press/new-odi-study-shows-how-gender-norms-are-holding-back-agriculture-inuganda/

28. Odie-Ali, S. (1986). Women in agriculture: The case of Guyana. Social and Economic Studies, 35(2), 241-289. http://www.jstor.org/stable/27862843

29. Pakissan. (2018).Women in Pakistan agriculture. https://www.pakissan.com/2018/12/12/women-inpakistan-agriculture/

30. Polman, W. (n.d.). Role of government institutions for promotion of agriculture and rural development in Asia and the Pacific Region - Dimensions \& issues [Resource paper]. http://www.fao.org/3/ad709e/ad709e.pdf

31. Ramsundar. (2017). Women farmers: The Invisible face of agriculture. IMOT Forum. http://www.imotforum.com/2017/06/hidden-face-women/

32. Regan, C. (2020). Is the world on track to achieve zero hunger by 2030? Five takeaways from 2 key reports. https://developmenteducation.ie/feature/is-the-world-on-track-to-achieve-zero-hunger-by2030-five-takeaways-from-2-key-reports/

33. Sutton, S. (2021). Empowering women in agriculture.

34. Sweeney, E., \& Levine, M. (2020). Empowering women in agriculture through responsible investing: Perspectives from Asia. Safin. https://www.safinetwork.org/post/empowering-women-inagriculture-through-responsible-investing-perspectives-from-asia

35. The World Bank. (2021). Agribusiness and value chains. https://www.worldbank.org/en/topic/agribusiness

36. Tosh, B. (2021). Women in agriculture: \#Choose To Challenge gender stereotypes. https://www.mnp.ca/en/insights/directory/women-in-agriculture-choose-to-challenge-genderstereotypes

37. Trauger, A. (2004). 'Because they can do the work': women farmers in sustainable agriculture in Pennsylvania, USA. Gender Place and Culture: A Journal of Feminist Geography, 11(2), 289-307.

38. UN Women (2013). The role of women in rural development, food production and poverty eradication. https://www.unwomen.org/en/news/in-focus/rural-women-day/2013 
39. UN Women. (2012). Empowerment of women in rural areas is pre-requisite for global food security [Press release]. UN Women, FAO, IFAD and WFP. http://www.unwomen.org/en/news/stories/2012/9/press-release

40. UNDP. (2020). The next frontier: Human development and the anthropocene: Briefing note for countries on the 2020 Human development report: Guyana. http://hdr.undp.org/sites/all/themes/hdr_theme/country-notes/GUY.pdf

41. Yohanna, M., \& Damisa, M. (2007). Role of rural women in farm management decision making process: Ordered probit analysis. World Journal of Agricultural Sciences, 3(4), 543-546. 